\title{
A MARX CENTENNIAL IN HAIFA
}

Monday, November 11, 1985 saw a seminar at the University of Haifa, on 'The Centennial of the Death of Karl Marx'. This seminar was sponsored by the University's Faculties of Humanities, and of Social Sciences and Mathematics, the Department of Political Science, the Center for German History and Culture, and the Goethe-Institut of Tel-Aviv.

Four speakers were featured:

Richard Löwenthal (Free University of Berlin), 'The Influence of Karl Marx on the SPD of Today',

Avraham Yassour (Haifa, Department of Political Science), 'The Late

Marx and the Russian Obščina', Hans Pelger (Karl-Marx-Haus, Trier), 'Karl Marx and Trier', Michael Maidan (Haifa, Philosophy Department), 'Karl Marx and the Jewish Problem',

The first of these can be found in English in the January 1984 issue of Encounter (London).

We are pleased to present herewith the other three to the readers of Studies in Soviet Thought. 